January 2015

\title{
Information Literacy in the Digital Age
}

Adrienne Mathewson

desertrhythm@gmail.com

Follow this and additional works at: https://scholarworks.sjsu.edu/ischoolsrj

Part of the Archival Science Commons, Cataloging and Metadata Commons, Collection Development and Management Commons, Information Literacy Commons, Scholarly Communication Commons, and the Scholarly Publishing Commons

\section{Recommended Citation}

Mathewson, A. (2016). Information Literacy in the Digital Age. School of Information Student Research Journal, 5(2). https://doi.org/10.31979/2575-2499.050201 Retrieved from https://scholarworks.sjsu.edu/ ischoolsrj/vol5/iss2/1

This article is brought to you by the open access Journals at SJSU ScholarWorks. It has been accepted for inclusion in School of Information Student Research Journal by an authorized administrator of SJSU ScholarWorks. For more information, please contact scholarworks@sjsu.edu. 


\section{Information Literacy in the Digital Age}

\section{Keywords}

mobile, information literacy, Issue 2, Student Research Journal, iSchool

\section{About Author}

Adrienne Mathewson is an Independent Information Professional in her final semester at San Jose State University's School of Information. She is the Editor-in-Chief of the Student Research Journal and resides in Albuquerque, New Mexico. 
I'm proud to announce the iSchool Student Research Journal's (SRJ) publication of second issue of Volume 5. This issue highlights the importance of technology in the LIS field, which has expanded the field in interesting ways. Information Professionals are not only rising to the challenge of providing information through technology but are creating the means for patrons to increase their information literacy. No longer does a student or researcher have to walk into a physical space in order to find material. Librarians use digital services as diverse as geospatial technology, mobile devices, genealogy software, blogs, e-readers, and websites to provide access to patrons.

However, as we see in these papers, despite all the fun and convenience of digital technology, sometimes a hard copy of a research document inside a brick \& mortar library found with the assistance of a helpful librarian remains the best way to help our patrons.

The four articles that passed the journal's rigorous peer review article and Dr. Ziming Liu's Invited Contribution focus on the many ways LIS professionals contribute to information literacy through technology.

Dr. Liu's article "Information Behavior in the Mobile Environment: An Overview" reflects the increasing use of mobile devices and highlights the findings of his project to investigate mobile information behavior among undergraduate students in China. Motivations, strategies, preferences, and the implications of this type of behavior to LIS professionals are outlined in his article.

"Rethinking Assessment: Information Literacy Instruction and the ACRL Framework" by Melissa Anderson, discusses the increase of information literacy instruction by university librarians and the need for effective evaluation of this service. In particular, Anderson stresses that in order to "design assessment exercise that align with the learning goals of the (ACRL) Framework.....a variety of contemporary, collaborative educational tools, such as guided group discussions, online discussion boards, and social media platforms" is necessary.

Catherine Lucy's article continues the theme of the unusual and unexpected ways that technology is changing the information world. "Research Trends \& Emerging Technologies for Genealogists" studies the rise in the use of technology to assist genealogists in their quest to find their family roots. This study focuses on "... traditional tools and methods utilized by genealogists... and an analysis of emerging research trends and technologies that are popular with today's genealogy community".

I found Gina Nichols' article, "Merging Special Collections with GIS Technology to Enhance the User Experience" especially fascinating as I am unfamiliar with Geographic Information System (GIS) technology. As Nichols' says, "Twenty-first century collection managers have reached a point where they must provide more innovative digital services to patrons or risk becoming irrelevant" as she discusses how merging geospatial technology with historic materials is transforming special collections with this cutting technology.

The final article "The Tumblarians" by Tamarack Hockin discusses the emerging trend of microblogging and the freshly coined term 'tumblarians' a combination of' tumblr' (a popular microblog site) and 'librarian'. This paper explores how tumblarians fit within existing LIS literature and provides a preliminary examination into their community.

This issue was pulled together through the efforts of SRJ's Managing Editor, Janet Casey, and her hard-working editorial team. Content editors Josh Smith, Camille Peters, Kristen Clark, Melissa Anderson, Devon Lee, and Rebecca Padrick worked hard in their roles as peer reviewers along with copy editors Mary Alice Kolonay and Laurel Diskin. 
I thank everybody who contributed to this issue including those graduate students who submitted their manuscripts for review. A special Thank You to Dr. Bernier, our Faculty Advisor, who continues to give his time and expertise to SRJ. As well, I sincerely thank our Editorial Board members, faculty and iSchool administrators for their continued support of iSchool's Student Research Journal. 